\title{
Autologous CD19/CD22 Chimeric Antigen Receptor T-cells
}

National Cancer Institute

\section{Source}

National Cancer Institute. Autologous CD19/CD22 Chimeric Antigen Receptor T-cells. NCl Thesaurus. Code C142834.

A preparation of autologous human T-lymphocytes eng ineered to express a chimeric $\mathrm{T}$ cell receptor (chimeric antigen receptor or CAR) consisting of one or more binding domains targeting the tumor-associated antigens (TAAs) CD19 and CD22 and fused to one or more co-stimulatory TCR-signaling domains, with potential immunostimulating and antineoplastic activities. Upon administration, the autolog ous CD19/CD22 CAR Tcells bind to CD19 and CD22 on the surface of, and induce selective toxicity against, tumor cells expressing CD19 and CD22. CD19 and CD22, both transmembrane phosphoglycoproteins expressed on the surface of cells in the B lineage, are overexpressed on malignant B-cells. 